\title{
Role of Police in the Criminal Justice System of Bangladesh: Need for Reformation
}

\author{
Sunjida Islam \\ Department of Law, Rajshahi Science and Technology University, \\ Natore, Rajshahi, Bangladesh \\ E-mail: sunjidaislam199320@gmail.com
}

Type of the Paper: Research Paper.

Type of Review: Peer Reviewed.

Indexed in: OpenAIRE.

DOI: http://doi.org/10.5281/zenodo.2654464.

Google Scholar Citation: IJMTS

\section{How to Cite this Paper:}

Sunjida Islam. (2019). Role of Police in the Criminal Justice System of Bangladesh: Need for Reformation. International Journal of Management, Technology, and Social Sciences (IJMTS), 4(1), 46-51. DOI: http://doi.org/10.5281/zenodo.2654464.

International Journal of Management, Technology, and Social Sciences (IJMTS) A Refereed International Journal of Srinivas University, India.

(C) With Author.

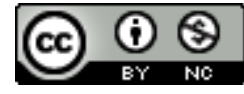

This work is licensed under a Creative Commons Attribution-Non Commercial 4.0 International License subject to proper citation to the publication source of the work.

Disclaimer: The scholarly papers as reviewed and published by the Srinivas Publications (S.P.), India are the views and opinions of their respective authors and are not the views or opinions of the SP. The SP disclaims of any harm or loss caused due to the published content to any party. 


\title{
Role of Police in the Criminal Justice System of Bangladesh: Need for Reformation
}

\author{
Sunjida Islam \\ Department of Law, Rajshahi Science and Technology University, \\ Natore, Rajshahi, Bangladesh \\ E-mail: sunjidaislam199320@gmail.com
}

\begin{abstract}
Police and their functions are very important in criminology. Because it is the principal duty of the police to arrest criminals and conduct them until the conclusion of trial for preventing crime. Police are legally authorized to use force and other means of coercion to execute public and social order. The basic knowledge of crime and criminology is must for the police and that's why almost in every country of the world has a criminology division for police. And police are manually trained for the knowledge of criminology. It is true that an honest, sincere and effective police force can ensure a happy and peaceful society. Although it is not possible for the police to reduce crime from society completely but it can be controlled and retained in a satisfactory stage. Otherwise, trick, corrupted, unlettered and disingenuous police force can give facilities to the criminals and make the life of the general citizens miserable. This study has an assertion and provided some recommendations to the knowledge of criminology for police and to reform the police system in Bangladesh. This article provides strategic policy guidance for the police personnel.
\end{abstract}

Keywords: Police, Crime, Criminology, Reform and Justice.

\section{INTRODUCTION :}

In the nineteenth century, the science of police was introduced as a branch of social and political economy. This branch is handling the problem of crime and social disorder and considering how to improve the policies to reduce and control them. In this sense, police are used to mean a system of governing the society by social, cultural, political and economic policy. Now, police are a small part of the whole domestic government and an effective agency for the criminal justice system. The police are state agency which has a broad mandate for controlling crime and maintaining order. It is presumed that police can be a functional prerequisite for social and public order but experimental studies expressed that many societies have existed without a formal police force. Some anthropological studies have shown that many pre-literate societies have been subsisted without any system of policing and social control. The studies have shown an intimate relationship between social complexity and legal evolution. A recent study has linked the development of police force to become specialized which may be occurred in the evolution from kinship to a class dominated society.

\section{GENERAL CONCEPT OF POLICE:}

The term 'police' originated from the French and less directly from the Greek word 'politeia' which means government or civil administration. The word 'police' was generated in France in the eighteenth century. In France, it was also known as constabulary and later constables who were an effigy of police officers. In the ancient periods, the military was liable for the law and order in urban areas. After that, the Roman Empire had made an effective law enforcement system by launching a police force 
in Rome. But in the case of lands local lords and nobles executed the order. And when a critical situation has arisen due to unpaid they often appointed constable to enforce the law [1].

\section{POLICE IN DIFFERENT COUNTRIES :}

The first law enforcement body was established by London in 1663 when hired watchman to patrol the streets at night. After that the Glasgow police Act was enacted in 1800 and established the city police for Scotland. Following this instance, in 1829 the British Parliament passed the Metropolitan Police Act and formed London Metropolitan Police [2]. It became model for many countries and following this the New York city of the United States established the first organized police force in 1845. There are two levels of police forces in Australia and Brazil, federal police force and state police force. But Canada has three levels of police as municipal, provincial and federal. In France there are two types of police, administrative police and judicial police. Because here the term 'police' does not only mean to the forces but also refers to the policing in general sense of 'maintenance of law and order'. Administrative police force remains under the law enforcing body on the other hand judicial police remains under the authority of Judge. In Indian sub-continent, the police system was introduced during the Mughal period. But in 1858, after taking directly the responsibility of India by British Crown the police system was reorganized. To prevent and reduce crime the British rulers sometimes enacted some codes like Indian Penal Code in 1860, the Criminal Procedure Code in 1861 and the Police Code in 1861. Around 150 years have elapsed but still Bangladesh police organization follows these Codes [3]. Bangladesh police commenced their functions from $16^{\text {th }}$ December, 1971. It is a disciplined force within the meaning of Article 152 of the Constitution of the People's Republic of Bangladesh. According to different laws of Bangladesh it is a structured force which have network all over the country. Though the police Act, 1861 is an adopted law but later the government of Bangladesh inserted some rules and orders in that Act.

\section{REFORM OF POLICE IN BANGLADESH :}

In 1948, a munity was organized in Dhaka by the east Pakistan police. In this context a commission was formed with Justice Shahabuddin as chair to reform the police. But the report of this commission was not implemented. Later to reduce the police chaos two police commissions were formed in 1959 and in 1969 but recommendations of none were implemented by the government. After the establishment of Bangladesh another police commission was formed in 1986 with Toiabuddin Ahmed as president. But some recommendations of the report of the commission were accepted partially by the government for implementation. In 1988 further a police commission was formed with Justice Aminur Rashid as leader and the government partially implemented the recommendations of the commission [4]. A several police commissions were formed in different times to reform the police. But successive measures were not taken to implement the recommendations. That's why police are still considered as corrupt, oppressive and abuser. So an effective reform is emergency for police administration.

\section{CONTRIBUTION OF POLICE IN THE CRIMINAL JUSTICE SYSTEM :}

Police have various types of functions in the criminal justice system. A modern country can't think the operation of its judicial system without a stable police force and their functions.

(1) Police arrests suspected criminal and law violators. To prevent misdeeds of criminal police takes them under custody and brings them before a criminal court. Police tries to put a bar on criminal activities through this process.

(2) Another important function of the police is to investigate criminal activities. Police can exercise power under sections 154 to 176 of the Code of Criminal Procedure to investigate a criminal case. After completion of investigation, police submit a charge-sheet for prosecution or final report for release of the accused.

(3) A police officer may examine orally any supposed person who is acquainted with the facts and circumstances of the case. Section 61 
and 167 of the Code of Criminal Procedure provide the power of interrogation of the police. A person who is arrested without warrant should be examined within 24 hours under section 61 or if not then within 15 days under section 167 [5]. So it is very important function of the police to find out the truth behind the commission of crime.

(4) Search and seizure are very significant functions of police. Sections 96 to 105 of the Code of Criminal Procedure discusses about the mode and procedure of search and seizure. To conduct search and seizure police should follow fair and reasonable procedure. Police may conduct this function with or without any warrant.

(5) A police officer fulfills his duty to make an inquest report on a person who has committed suicide or has died under a reasonable suspicion or has been killed by another or died unnaturally. A police officer describes on the report the actual conditions of the body, states in what manner or by what weapon or instrument may be used for committing the offence [6].

(6) Sometimes a police officer plays a vital role as a prosecutor. In the case of criminal offence, the responsibility lies on the state to bring the accused before the court. Then police investigate to find out the real offender and public prosecutor conducts the case on behalf of the state. In collaboration with police and public prosecutor may successfully reduce the crime.

So from the above discussion it may be said that police play an important role in the criminal justice system of Bangladesh to reduce and prevent crime.

\section{LIMITATION OF POLICE UNDER DIFFERENT LAWS OF BANGLADESH :}

Police can't function smoothly due to some provisions of the Code of Criminal Procedure and the Evidence Act. It is mandatory for the police under the Code of Criminal Procedure to take at least two respectable persons from the locality to enter any premise for search and seizure [7]. But sometimes police do not find two respectable inhabitants to associate with them. It is a great obstacle for the police to perform in their activities smoothly. When a police officer takes any statement from any person in the course of investigation then that statement can't be used as evidence at any inquiry or trial of the court. Because this statement has no very evidentiary value, the police officer expresses a contradictory picture due to very limited evidentiary value of the statements. Under the evidence Act when a confession is given to a police officer in the absence of Magistrate this confession is not admissible as evidence in a court [8]. It creates an unnecessary hardship to the police in their activities in the criminal justice system.

\section{CORRUPTION AND ABUSE OF POWER BY POLICE :}

Although the police department contributes vitally through its activities in the criminal justice system of Bangladesh but it has been stigmatized as corrupt and has abused their power in different circumstances. Several times police department has been identified by Transparency International as the most corrupt department among all the departments of the Bangladesh government [9]. A survey report of Transparency International revealed that around 83 and 75 percent citizens victimized for corruption of police department and lower judiciary respectively [10]. There are complaints about police for indiscriminate arrest of innocent persons under section 54 of the Code of Criminal Procedure. Sometimes victims are remanded to the custody of the police under section 167 of the same code and subjected to third degree methods in order to extract confession. In considering this matter a division Bench of the High Court Division issued eleven guidelines for the police and magistrates as to exercise their powers. The Supreme Court thinks that these guidelines will reduce the abusive power of the police [11].

\section{PROBLEMS OF THE POLICE IN BANGLADESH :}

Police are the important structure and a large embodiment of the Bangladesh government to execute the rules and orders. But this police force faces many problems in Bangladesh which are follows- 
(1) The police Act, 1861 emphasizes on the constabulary activities of the police more than focusing the professional aspect of controlling crime. Thus, the police can't understand clearly the role and responsibility to control crime.

(2) Majority members of the police force belong to low ranking like constable and they have no educational and intellectual prevalence. That's why their treatment to the general people is very rude and abusive.

(3) Police can't provide services to the common people properly due to lack of proper training and motivation.

(4) Salary given to the police officers particularly to the constable level is not sufficient.

(5) Police face the problem of inadequate logistic support like insufficient staffs sit in each room, narrow room in the police station and unhygienic toilet facilities.

(6) Some police stations have no separate room for meeting or conference and sufficient number of cars as well as prison vans.

(7) Police officers do not get sufficient time to investigate criminal cases. That's why they often fail to control crime.

(8) A large number of police is used as a branch of governmental political organization and used against the rightful activities of the opposition political parties.

(9) They have no proper criminal behavior knowledge under criminology.

(10) Police department of Bangladesh faces problems both internal and external due to lacks of proper accountability.

(11) Sometimes they face unethical problems imposed by the ruling party.

\section{RECOMMENDATIONS :}

The aim of the police Act, 1861 is to maintain the public and social order as well as also to maintain the status quo. The fundamental duty of the police force is to control crime and give services to the common people. To fulfill the principal objectives of the police and to make them more effective the following recommendations should be followed.

(1) Government should establish a professional police organization to effectively control crime.
(2) A new police Act should be enacted and a public safety commission or a security commission should be formed.

(3) The emergency provisions and preventive detention provisions should be amended to protect human rights.

(4) The conditions of detention and interrogation by the police during remand should be carefully scrutinized by the judges.

(5) The time of police investigation should be extended with accountability.

(6) Proper training and motivational facilities should be provided to the police.

(7) The performance of the police should be evaluated in every year by the government.

(8) The excessive political uses of the police force should be reduced by the government or ruling party.

(9) Sufficient logistic supports in the different police stations should be provided without any delay.

(10) Police should be provided proper knowledge regarding crime and criminal behavior under criminology.

(11) Effective guidelines should be provided to the police for preventive and service-oriented functions.

\section{CONCLUSION :}

The structure of Bangladesh police within which they are working was established by the British rulers. After the establishment of Bangladesh, we got a readymade police force and government kept same the previous structure of police. To reform the police structure, the government of Bangladesh has taken different initiatives several times but no implementation has done for establishing a professional police force in the country. The whole machinery of the government is well aware of the corruption, illegal arrest, torture, manipulation and other malpractice of police. Despite that they are functioning with this deviated police force. The activities of police are negatively practiced against the opposition party citizens but when they come in the power they defend the same police force and use them for narrow party purpose. So lastly it may be said that government, local authorities, voluntary 
organizations, individual citizens and the police all can play an important role to establish a civil society where there will be no crime and common people will not fall in cruel torture.

\section{REFERENCES :}

[1] Police- Wikipedia, the free encyclopedia. http://en.wikipedia.org/wiki/Police.

[2] http://www.scotia-news.com/issue5/ ISSUE 05a.htm.

[3] Ahmad Siddique, Criminology: Problems and Perspectives, Eastern Book Company, Lucknow, Fourth Edition, p. 281.

[4] Ahmed Amin Chowdhury, Bangladesh Police: Uttoradhicar O Babasthapana (in Bengali), Bangladesh Police: Heritage and Administration, pp. 87-94.

[5] Section 161 (1) of the Code of Criminal
Procedure, Bangladesh.

[6] Section 174 of the Code of Criminal Procedure, Bangladesh.

[7] Section 103 of the Code of Criminal Procedure, Bangladesh.

[8] Section 25 of the Evidence Act, Bangladesh.

[9] Working Paper on Police Stations, Transparency International Bangladesh, March 4, 2004, p. 3.

[10] The Daily Bhorer Kagoj, December 21, 2001.

[11] Moazzam Husain, M. (2004). "Police Custody, Custodial Interrogation and Right to Silence: Bangladesh Perspective," Law and Our Rights page, The Daily Star, October 24, 2004. 